\title{
Vertically-Suspended Environmental Enrichment Structures Improve the Growth of Juvenile Landlocked Fall Chinook Salmon
}

\author{
Alex J. Rosburg' ${ }^{1}$, Brian L. Fletcher ${ }^{1}$, Michael E. Barnes ${ }^{2}$, Cody E. Treft ${ }^{1}$, Blaise R. Bursell ${ }^{1}$ \\ ${ }^{1}$ South Dakota Department of Game, Fish, and Parks, Cleghorn Springs State Fish Hatchery, 4725 Jackson \\ Boulevard, Rapid City, South Dakota 57702, USA \\ ${ }^{2}$ South Dakota Department of Game, Fish, and Parks, McNenny State Fish Hatchery, 19619 Trout Loop, \\ Spearfish, South Dakota 57783, USA
}

*Corresponding Author: Alex J. Rosburg, South Dakota Department of Game, Fish, and Parks, Cleghorn Springs State Fish Hatchery, 4725 Jackson Boulevard, Rapid City, South Dakota 57702, USA

\begin{abstract}
Environmental enrichment is the use of structures or materials to create more natural or complex environments in hatchery rearing units. This study assessed the effects of two types of enrichment structures on the growth of juvenile landlocked fall Chinook salmon (Oncorhynchus tshawytscha) reared in semi-square tanks. The structures were vertically-suspended arrays of either five half-round polyvinyl chloride pipes or six golf balls affixed vertically on threaded rod (spherical enrichment). After 90 days, both enrichment treatments produced significantly greater weight gains than the unenriched control. Total fish length was significantly different among all three treatments, and was highest in fish reared with spherical enrichment. Individual weight, condition factor, and relative dorsal and pectoral fin length also differed between enriched tanks and the control, but did not significantly differ between enrichment types. The results of this study support the use of vertically-suspended enrichment structures to improve juvenile Chinook salmon growth during hatchery rearing.
\end{abstract}

Keywords: Environmental Enrichment; Chinook salmon, Oncorhynchus tshawytscha; growth; verticallysuspended structure

\section{INTRODUCTION}

Environmental enrichment is the addition of structures or materials to create a more natural or complex environment in otherwise stimuli-deprived hatchery rearing units. It has been used in an attempt to improve post-stocking survival (Berejikian et al. 1999; Fast et al. 2008), but some forms of enrichment have also shown the potential to improve foraging efficiency, reduce fin damage, and promote greater social dominance in hatchery-produced fish (Bosakowski and Wagner 1995; Berejikian et al. 2001; Rodewald et al. 2011). Structural additives meant to imitate natural environments, including sand and gravel substrates, stones, woody debris, and live prey have been common methods of enriching rearing tanks and raceways (Brown et al. 2003; Brockmark et al. 2007). However, the use of natural substrates and structures can impede circular tank hydraulic selfcleaning, increasing the time required to perform routine culture activities and also creating conditions favorable to pathogenic bacteria (Baynes and Howell 1993; Tuckey and Smith 2001; Krebs et al. 2017).

Recent studies have documented positive effects on salmonid growth and feed conversion ratios from vertically-suspended arrays which do not disrupt the self-cleaning nature of circular tanks (Kientz and Barnes 2016; Krebs et al. 2018; White et al. 2019; Kientz et al. 2018, Crank et al. 2019). However, White et al. (2018) did not observe any benefits using suspended structure during a relatively short period of juvenile Chinook salmon Oncorhynchus tshawytscha rearing.

The reason why the White et al. (2018) study results were different than those consistently observed in other studies using suspended structure is unknown. While it may possibly be due to species- 
specific responses to environmental enrichment, it may also have been because of the type of structure used or the relatively short duration of the study. While White et al. (2018) used vertically-suspended aluminum rods, Kientz et al. (2018) and Crank et al. (2019) reported positive effects from verticallysuspended strings of spheres. The objective of this study was to investigate the use of two novel vertically-suspended enrichment arrays for an extended time on the growth and survival of hatchery reared Chinook salmon.

\section{MATERiAls AND MethodS}

This 90-day study was conducted at Cleghorn Springs State Fish Hatchery, Rapid City, South Dakota, USA, using $11^{\circ} \mathrm{C}$ spring water (total hardness as $\mathrm{CaCO} 3,36 \mathrm{mg} \mathrm{L}-1$; alkalinity as $\mathrm{CaCO}, 210 \mathrm{mg} \mathrm{L}-$ 1; pH, 7.6; total dissolved solids, $390 \mathrm{mg} \mathrm{L}-1$ ). The Chinook salmon used in this study originated from eggs spawned on 17 October 2017, and all of the fish used in the study were reared similarly prior to the start of the experiment. A flow-through system consisting of 12 semi-square 190-liter tanks with partial $(\sim 50 \%)$ overhead covers was used (Figure 1$)$. Each tank was randomly assigned one of three treatments $(\mathrm{N}=4): 1$. half-round pipearray [five $40.6 \mathrm{~cm}$ tall, $3.2 \mathrm{~cm}$ outside diameter polyvinyl chloride (PVC) pipe cut in half vertically (Figure 2)], 2. Spherical array [9.5 mm threaded rod with six $4.3 \mathrm{~cm}$ spheres (golf balls) spaced approximately $2.5 \mathrm{~cm}$ apart (Figure 3)], or 3. control (no enrichment). For both enrichment treatments, structures were suspended from the tank covers directly opposite of the spray bars where water entered the tank. Structures were arranged $7.6 \mathrm{~cm}$ apart and spaced $7.6 \mathrm{~cm}$ from the outer wall of the tank (Figure 4). Inflow to each tank was $12 \mathrm{l} / \mathrm{min}$ and water velocities were negligible $(<0.1 \mathrm{~m} / \mathrm{s})$.

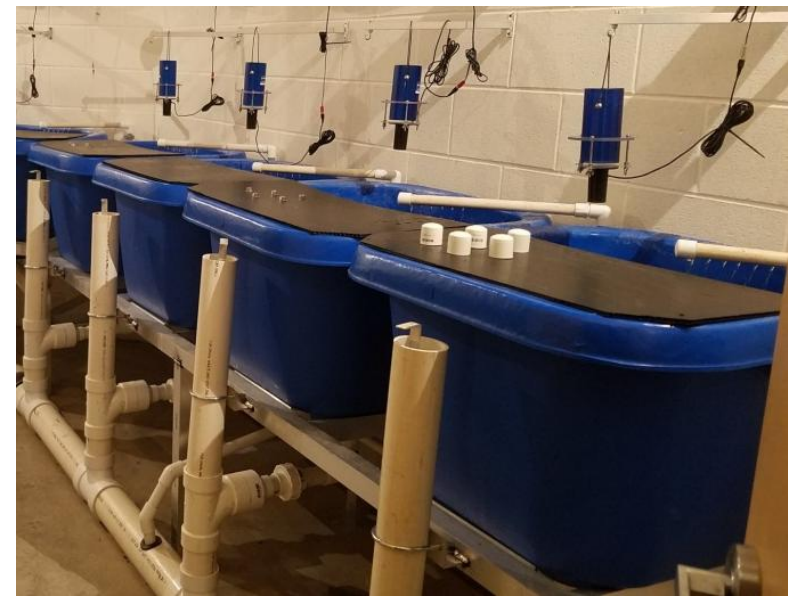

Figure1. Experimental system consisting of 190-liter tanks with partial ( $\sim 50 \%)$ overhead covers and randomly assigned treatments of half-round pipe array, spherical array, or control (no enrichment).

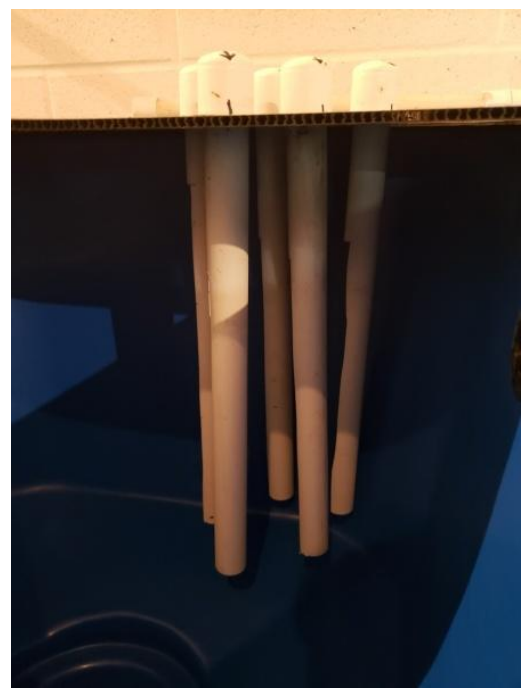

Figure2. Pipe enrichment array consisting of $40.6 \mathrm{~cm}$ tall, $3.2 \mathrm{~cm}$ outside diameter polyvinyl chloride pipe cut in half vertically. 


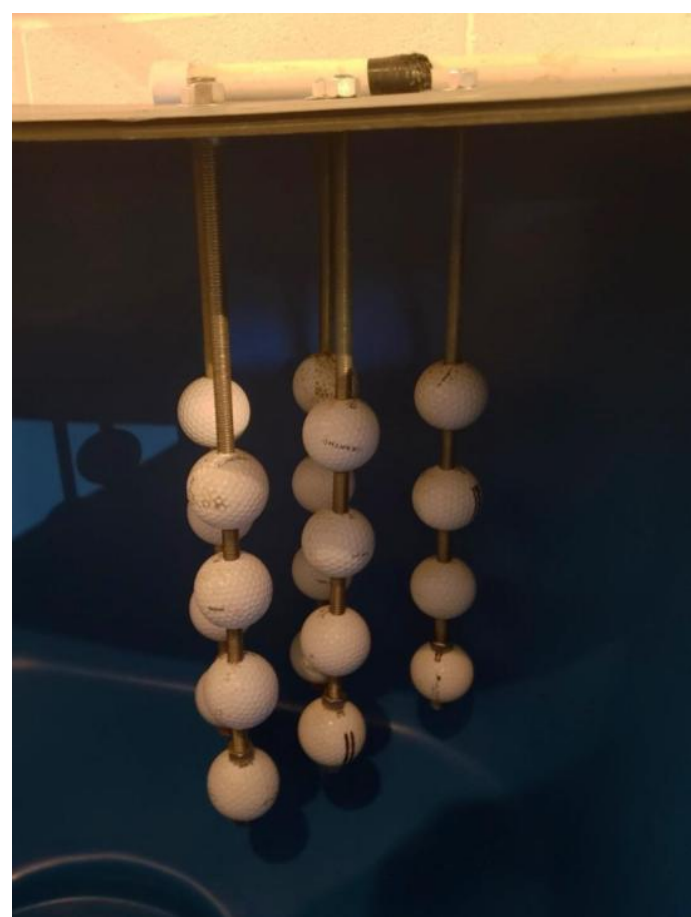

Figure3. Spherical enrichment array consisting of $9.5 \mathrm{~mm}$ threaded rods with six $4.3 \mathrm{~cm}$ spheres (golf balls) spaced approximately $2.5 \mathrm{~cm}$ apart.

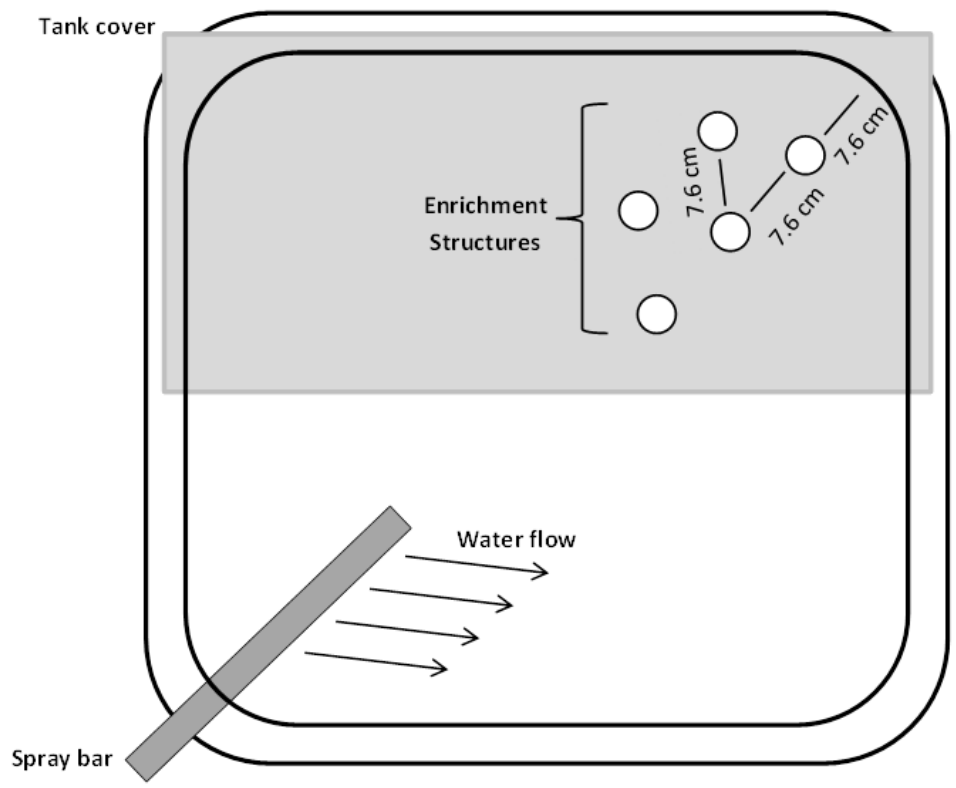

Figure4. Top view (not to scale) of a 190 liter tank showing the location of vertically-suspended structures

Beginning on February $16^{\text {th }}, 2018$, each tank received 200 juvenile fall Chinook salmon $(\mathrm{mean} \pm \mathrm{SD}$; initial weight $=2.6 \pm 0.9 \mathrm{~g}$; total length $=67.9 \pm 7.8 \mathrm{~mm} ; n=30)$ and initial tank weights were recorded to the nearest $0.01 \mathrm{~kg}$. Fish were fed $1.0 \mathrm{~mm}$ extruded sinking pellets (Skretting salmon; Toele, Utah, USA) to satiation for the duration of the trial. Vibratory feeders (Pentair Aquatic Eco-Systems, Inc., Apopka, Florida, USA) connected to a timer (Sweeney Enterprises Inc., Boerne, TX, USA) delivered feed at 60 minute intervals. Mortalities were removed and recorded daily. At the end of the study, total tank weights were determined by weighing all fish in each tank to the nearest $0.01 \mathrm{~kg}$ and weight gain was calculated using the formula: Gain = Final Tank Weight - Initial Tank Weight. A subsample of 20 fish per tank was then randomly selected, with each fish individually weighed to the nearest $0.01 \mathrm{~g}$ and total length measured to the nearest $0.1 \mathrm{~mm}$. Condition factor $(\mathrm{K})$ was calculated as [(weight, g)/(length, $\left.\mathrm{cm})^{3}\right] \times 10^{5}$ for each tank. Additionally, pectoral and dorsal fin lengths were measured, and relative fin length calculated as (fin length/body length) $\times 100$ (Bosakowski and Wagner 1994). 
Data analysis was conducted in R Studio version 0.99.902 (R Foundation for Statistical Computing, Vienna, Austria) using one-way analysis of variance (ANOVA) to test for differences in gain and mortality between treatments. Because the tanks were the experimental units, a nested ANOVA was used to test for differences in individual fish data (length, weight, condition factor, relative fin length). For all analyses, data was considered significantly different at $P$-values less than 0.05 .

\section{RESUlts}

Gain did not significantly differ between the two enrichment treatments, but both were significantly greater than the control $(F=11.34, P=0.003$; Table 1$)$. Mortality did not differ between treatment groups.

Individual fish total length was significantly different between both enrichment treatments and the control, with spherically-enriched tanks producing the longest fish $(F=29.24, P=<0.001$; Table 2). Individual fish weights were also significantly greater in the enriched tanks compared to the control, but were not different between the enrichment treatments $(F=22.37, P=<0.001)$. Additionally, salmon reared in tanks with enrichment structures developed longer relative dorsal fin lengths $(F=$ 16.73, $P=<0.001)$ and pectoral fin lengths $(F=15.12, P=<0.001$; Table 2$)$ compared to controls. However there were no differences in relative fin lengths between the enrichment treatments. No significant differences were observed in condition factor or mortality between the treatments.

Table1. Mean (SD) gain and percent mortality of juvenile Chinook salmon reared in environmentally-enriched or control semi-square tanks. Means within the same row with different letters are significantly different $(P$ $=<0.05, n=4)$.

\begin{tabular}{|l|c|c|c|}
\hline & \multicolumn{3}{|c|}{ Enrichment } \\
\hline Variable & None(control) & PVC & Spherical \\
\hline Gain $(\mathrm{kg})$ & $1.37(0.38) \mathrm{x}$ & $2.14(0.27) \mathrm{y}$ & $2.27(0.19) \mathrm{y}$ \\
\hline Mortality (\%) & $4.4(4.0) \mathrm{x}$ & $1.1(1.9) \mathrm{x}$ & $1.6(1.3) \mathrm{x}$ \\
\hline
\end{tabular}

Table2. Mean (SD) total length, weight, condition factor $\left(K ;\left[\{\text { weight,g\}/\{length, } \mathrm{mm}\}^{3} \times 100\right)\right.$, relative fin lengths (\%; [fin length/total length] $\times 100)$ of juvenile Chinook salmon reared in environmentally enriched and control semi-square tanks. Means within the same row with different letters are significantly different $(P$ $=<0.05, n=4)$.

\begin{tabular}{|l|c|c|c|}
\hline \multirow{2}{*}{ Variable } & None(control) & PVC & Spherical \\
\hline & $101.5(3.7) \mathrm{x}$ & $112.0(2.9) \mathrm{y}$ & $117.8(2.6) \mathrm{z}$ \\
\hline Length $(\mathrm{mm})$ & $9.83(1.52) \mathrm{x}$ & $13.51(1.61) \mathrm{y}$ & $15.55(0.79) \mathrm{y}$ \\
\hline Weight $(\mathrm{g})$ & $0.88(0.02)$ & $0.91(0.03)$ & $0.91(0.03)$ \\
\hline K & $11.76(0.24) \mathrm{x}$ & $13.53(0.22) \mathrm{y}$ & $13.81(0.38) \mathrm{y}$ \\
\hline Dorsal fin $(\%)$ & $10.32(0.46) \mathrm{x}$ & $12.01(0.42) \mathrm{y}$ & $12.47(0.38) \mathrm{y}$ \\
\hline
\end{tabular}

\section{DISCUSSION}

The improved growth of the Chinook salmon reared with vertically-suspended environmental enrichment in this study is similar to the results observed with rainbow trout Oncorhynchus mykiss and brown trout Salmo trutta (Kientz and Barnes 2016; Kientz et al. 2018; Crank et al. 2019; White et al. 2019). However, the results differ from those reported by White et al. (2018) for Atlantic salmon Salmo salar and Chinook salmon. It is possible that the effects of enrichment may be species-specific (Näslund and Johnsson 2016), but this would only explain the results observed with Atlantic salmon by White et al. (2018). Why did the results with Chinook salmon reported by White et al. (2018) differ from those obtained in this study? Both of the studies used the same strain of Chinook salmon, but this study lasted approximately 15\% longer, potentially providing the necessary time for any growth improvements to become evident (Brockmark et al. 2007). In addition, the verticallysuspended structures (simple aluminum rods) used in White et al. (2018) were different than the much more complex structures used in this study. Lastly, White et al. (2018) used $1.8 \mathrm{~m}$ diameter circular tanks, while this study used considerably smaller semi-square rearing units. 
It is possible that color may have had some effect on the results of this study. Kientz et al. (2018) used spheres of various colors in their vertically-suspended structures. This study was conducted in blue walled tanks and used only white PVC and spheres (golf balls) in enrichment structures. While the effects of color on rearing performance are not well understood, some tank wall colors have been associated with increased growth (Tamazouzt et al. 2000; Karakatsouli et al. 2007; Eslamloo et al. 2015). Ambient color can also increase (Eslamloo et al. 2015) or decrease (Volpato and Bareto 2001; Luchiari and Pirhonen 2008) stress in certain species of fish.

While few studies have been conducted on vertically-suspended enrichment structures, other forms of tank enrichment (e.g. tank covers) and structural complexity (e.g. natural and artificial plants, gravel substrate, wood, rocks, and plastic tubing) have been found to produce small to moderate improvements in growth of various salmonids (Barnes and Durben 2003; Brown et al. 2003; Barnes et al. 2005; Brockmark et al. 2007). However, the improvements provided by these forms of enrichment are small in comparison to the $56 \%$ increase in weight gain observed in this study. In contrast to this study, some previous studies have found little to no improvement associated with added structure. Brockmark et al. (2007) found it took 311 days to see marginal improvements in Atlantic salmon growth. Similarly, there have been contrary results on growth differences associated with the use of tank covers (Pickering et al. 1987; Tabor and Wurtsbaugh 1991; Wagner and Bosakowski 1994; and Wagner et al. 1995).

The reasons for the increased growth of fish reared in structurally-complex or environmentallyenriched tanks are still unclear. Moine et al. (2016) examined flow patterns in circular tanks with and without vertical structures and found that the presence of vertically-suspended rods significantly reduced velocities at various sampling locations throughout the tank. These findings support the idea that flow disruption and the creation of reduced velocity microhabitats could minimize energy expended on fish movement, thereby allowing for increased energy allocation to growth (Fausch 1984). Results from water velocity studies involving Chinook salmon (Parker and Barnes 2014; Kiessling 1994) and brook trout Salvelinus fontinalus (Leon1986) indicating decreased growth at higher water velocities further support this hypothesis. We did not record fish use or location relative to enrichment structures. Data on how fish use enrichment structures and pockets of reduced water velocity could strengthen the understanding of enrichment structures effects and assist in improving future designs.

Fin erosion refers to damage or loss of the fin tissue and has been recognized as a common problem in hatchery raised salmonids (Latremouille 2003). Fin erosion can be caused by a wide variety of factors (Bosakowski and Wagner 1995; Miller et al. 1995; Wagner et al. 1997; North et al. 2006), and has been associated with lower post-stocking survival in multiple trout and salmon species (Bosakowski et al. 1994; Petersson et al. 2013). The increased relative dorsal and pectoral fin lengths observed in the enriched tanks in this study suggest that the enrichment structures were beneficial to overall fish health. Other studies have also documented increased fin lengths as a result of tank enrichment (Berejikian and Tezak 2005; Rosengren et al. 2017; Kientz et al. 2018).

Kientz and Barnes (2016) highlighted the importance of retaining the self-cleaning properties of modern rearing tanks in order for enrichment structures to be a viable option for use in a production hatchery. Traditional forms of tank enrichment (i.e. substrates, rocks, wood, etc.) generally rest on the bottom and/or sides of the tank and disrupt the circular flows which carry wastes to the drain in the center of the tank (Baynes et al. 1993; Tuckey 2001; Krebs et al. 2017). The vertically-suspended enrichment structures used in this study performed similarly to those described by Kientz and Barnes (2016) and Kientz et al. (2018), with no additional cleaning or maintenance required.

\section{CONCLUSION}

Both of the vertically-suspended enrichment structures used in this study improved the growth and fin condition of juvenile Chinook salmon compared to unenriched tanks. However, the improvement was more pronounced with the spherical enrichment array. Thus, either method of environmental enrichment would be appropriate to use during Chinook salmon rearing, but the use of spherical structures is recommended to maximize rearing performance. 


\section{ACKNOWLEDGEMENTS}

We thank Mycala Reed for her assistance with data collection in this study.

\section{REFERENCES}

[1] Berejikian, B. A., Smith, R. J. F., Tezak, E. P., Schroder, S. L., and Knudsen, C. M. (1999). Chemical alarm signals and complex hatchery rearing habitats affect antipredator behavior and survival of Chinook Salmon (Oncorhynchus tshawytscha) juveniles. Canadian Journal of Fisheries and Aquatic Sciences, 56(5),830-838.

[2] Fast, D. E., Neeley, D., Lind, D. T., Johnston,M. V., Strom, C. R., Bosch,W. J., Knudsen,C. M., Schroder, S. L., and Watson, B. D. (2008). Survival comparison of spring Chinook Salmon reared in a production hatchery under optimum conventional and semi-natural conditions. Transactions of the American Fisheries Society, 137(5), 1507-1518.

[3] Bosakowski, T., and Wagner,E.J. (1995). Experimental use of cobble substrates in concrete raceways for improving fin condition of Cutthroat (Oncorhynchus clarki) and Rainbow Trout (O. mykiss). Aquaculture, 130(2-3), 159-165.

[4] Berejikian, B. A., Tezak, E. P., Riley, S. C., and LaRay, A. L. (2001). Competitive ability and social behaviour of juvenile steelhead reared in enriched and conventional hatchery tanks and a stream environment. Journal of Fish Biology, 59(6), 1600-1613.

[5] Rodewald, P., Hyvärinen, P., and Hirvonen, H. (2011). Wild origin and enriched environment promote foraging rate and learning to forage on natural prey of captive reared Atlantic Salmonparr. Ecology of Freshwater Fish, 20(4), 569-579.

[6] Brown, C., Davidson,T., and Laland,K.(2003). Environmental enrichment and prior experience of live prey improve foraging behavior in hatchery-reared Atlantic Salmon. Journal of Fish Biology, 63(S1), 187196.

[7] Brockmark, S., Neregård, L.,Bohlin, T., Björnsson, B.T., and Johnsson, J. I.(2007). Effects of rearing density and structural complexity on pre- and post-release performance of Atlantic Salmon. Transactions of the American Fisheries Society, 136(5), 1453-1462.

[8] Baynes,S.M., and Howell, B.R. (1993). Observations on the growth, survival and disease resistance of juvenile common sole, Soleasolea L. Aquaculture and Fisheries Management, 24(1), 95-100.

[9] Tuckey, L.M., and Smith, T. I. (2001). Effects of photoperiod and substrate on larval development and substrate preference of juvenile Southern Flounder, Paralichthyslethostigma. Journal of Applied Aquaculture, 11(1-2), 1-20.

[10] Krebs, J., Crank, K.M., Krebs, E., and Barnes, M.E. (2017). Use of bottom structure and tank cover during rainbow trout rearing in circular tanks. Journal of Fisheries and Livestock Production, 5(3), 1-3.

[11] Kientz, J. and Barnes, M.E. (2016). Structural complexity improves the rearing performance of Rainbow Trout in circular tanks. North American Journal of Aquaculture, 78(3), 203-207.

[12] Krebs,E., Huysman, N., Voorhees, J.M., and Barnes, M.E. (2018). Suspended arrays improve rainbow trout growth during hatchery rearing in circular tanks. International Journal of Aquaculture and Fishery Sciences, 4(3), 27-30.

[13] White, S.C., Krebs, E., Huysman, N., Voorhees, J.M., and Barnes, M.E. (2019). Use of suspended plastic conduit arrays during Brown Trout and Rainbow Trout rearing in circular tanks. North American Journal of Aquaculture, 81(101-106).

[14] Kientz, J. L., Crank,K.M., and Barnes, M.E. (2019).Enrichment of circular tanks with vertically-suspended strings of colored balls improves rainbow trout rearing performance. North American Journal of Aquaculture, 80(2), 162-167.

[15] Crank,K.M., Kientz, J.L., and Barnes, M.E. (2018). An evaluation of vertically suspended environmental enrichment structures during Rainbow Trout rearing. North American Journal of Aquaculture, 81(94-100).

[16] White, S.C., Krebs, E., Huysman, N., Voorhees, J.M., and Barnes, M.E. (2018). Addition of vertical enrichment structures does not improve growth of three salmonid species during hatchery rearing. Journal of Marine Biology and Aquaculture, 4(1), 48-52.

[17] Bosakowski, T., and Wagner, E.J. (1994). Assessment of fin erosion by comparison of relative fin length in hatchery and wild trout in Utah. Canadian Journal of Fisheries and Aquatic Sciences, 51(3), 636-641.

[18] Näslund, J., and Johnsson, J.I. (2016). Environmental enrichment for fish in captive environments: effects of physical structures and substrates. Fish and Fisheries, 17(1), 1-30.

[19] Tamazouzt, L., Chatain, B., and Fontaine, P. (2000). Tank wall colour and light level affect growth and survival of Eurasian Perch larvae (Perca fluviatilis L.). Aquaculture, 182(1-2), 85-90. 
[20] Karakatsouli, N., Papoutsoglou, S.E., and Manolessos, G. (2007). Combined effects of rearing density and tank colour on growth and welfare of juvenile White Sea Bream DiplodussargusL. in a recirculating water system. Aquaculture Research, 38(11), 1152-1160.

[21] Eslamloo, K., Akhavan, S.R., Eslamifar, A., and Henry, M.A. (2015). Effects of background colour on growth performance, skin pigmentation, physiological condition and innate immune responses of Goldfish, Carassiusauratus. Aquaculture Research, 46(1), 202-215.

[22] Volpato,G.L., and Barreto, R.E. (2001). Environmental blue light prevents stress in the fish Nile Tilapia. Brazilian Journal of Medical and Biological Research, 34(8), 1041-1045.

[23] Luchiari, A.C., and Pirhonen, J. (2008). Effects of ambient colour on colour preference and growth of juvenile Rainbow Trout Oncorhynchus mykiss (Walbaum). Journal of Fish Biology,72(6), 1504-1514.

[24] Barnes, M.E., and Durben, D.J. (2003). Use of partial tank covers during hatchery rearing of feral Rainbow Trout. North American Journal of Aquaculture, 65(4), 344-348.

[25] Barnes, M.E., Miller, J., and Durben, D.J. (2005). Partial overhead tank cover use during feral Brown Trout rearing. North American Journal of Aquaculture, 67(4), 319-323.

[26] Pickering, A., Griffiths, R., and Pottinger, T. (1987). A comparison of the effects of overhead cover on the growth, survival and haematology of juvenile Atlantic Salmon, Salmo salar L., Brown Trout, Salmo trutta L., and Rainbow Trout, Salmo gairdneriRichardson. Aquaculture, 66(2), 109-124.

[27] Tabor, R.A., and Wurtsbaugh, W.A. (1991). Predation risk and the importance of cover for juvenile Rainbow Trout in lentic systems. Transactions of the American Fisheries Society, 120(6), 728-738.

[28] Wagner, E.J., and Bosakowski, T. (1994). Performance and behavior of Rainbow Trout reared in covered raceways. Progressive Fish-Culturist, 56(2), 123-129.

[29] Wagner, E.J., Ross, D.A., Routledge, D., Scheer, B., and Bosakowski, T. (1995). Performance and behavior of Cutthroat Trout (Oncorhynchus clarki) reared in covered raceways or demand fed. Aquaculture, 136(1-2), 131-140.

[30] Moine, J., Barnes, M.E., Kientz, J., and Simpson, G. (2016). Flow patterns in circular rearing tanks containing vertical structure. Journal of Fisheries and Livestock Production, 4(4), 204-207.

[31] Fausch, K.D. (1984). Profitable stream positions for salmonids: relating specific growth rate to net energy gain. Canadian Journal of Zoology, 62(3), 441-445.

[32] Parker, T.M., and Barnes, M.E. (2014). Rearing velocity impacts on landlocked fall Chinook Salmon (Oncorhynchus tshawytscha) growth, condition, and survival. Open Journal of Animal Sciences, 4(5), 244252.

[33] Kiessling, A., Higgs, D., Dosanjh, B., and Easles, J. (1994). Influence of sustained exercise at two ration levels on growth and thyroid function of all-female Chinook Salmon (Oncorhynchus tshawytscha) in seawater. Canadian Journal of Fisheries and Aquatic Sciences, 51(9), 1975-1984.

[34] Leon, K.A. (1986). Effect of exercise on feed consumption, growth, food conversion, and stamina of Brook Trout. Progressive Fish-Culturist, 48(1), 43-46.

[35] Latremouille, D.N. (2003). Fin erosion in aquaculture and natural environments. Reviews in Fisheries Science, 11(4), 315-335.

[36] Miller, S.A., Wagner, E.J., and Bosakowski, T. (1995). Performance and oxygen consumption of Rainbow Trout reared at two densities in raceways with oxygen supplementation. Progressive Fish-culturist, 57(3), 206-212.

[37] Wagner, E.J., Jeppsen, T., Arndt, R., Routledge, D.M., and Bradwisch, Q. (1997). Effects of rearing density upon Cutthroat Trout hematology, hatchery performance, fin erosion, and general health and condition. Progressive Fish-Culturist, 59(3), 173-187.

[38] North, B.P., Turnbull, J.F., Ellis, T., Porter, M.J., MIguad, H., Bron, J., and Bromage, N.R. (2006). The impact of stocking density on welfare of Rainbow Trout (Oncorhynchus mykiss). Aquaculture, 255(1-4), 466-479.

[39] Petersson, E., Karlsson, L., Ragnarsson, B., Bryntesson, M., Berglund, A., Stridsman, S., and Jonsson, S. (2013). Fin erosion and injuries in relation to adult recapture rates in cultured smolts of Atlantic Salmon and Brown Trout. Canadian Journal of Fisheries and Aquatic Sciences, 70(6), 915-921.

[40] Berejikian, B. A., and Tezak, E. P. (2005). Rearing in enriched hatchery tanks improves dorsal fin quality of juvenile steelhead. North American Journal of Aquaculture, 67(4), 289-293. 
[41] Rosengren, M., Kvingedal, E., Näslund, J., Johnsson, J. I., and Sundell, K. (2017). Born to be wild: effects of rearing density and environmental enrichment on stress, welfare, and smolt migration in hatchery reared Atlantic Salmon. Canadian Journal of Fisheries and Aquatic Sciences, 74(3), 396-405.

[42] Baynes, S. M., and Howell, B. R. (1993). Observations on the growth, survival and disease resistance of juvenile common sole, Soleasolea L. Aquaculture and Fisheries Management, 24(1), 95-100.

[43] Tuckey, L.M., and Smith, T.I. (2001). Effects of photoperiod and substrate on larval development and substrate preference of juvenile southern flounder, Paralichthyslethostigma. Journal of Applied Aquaculture, 11(1-2), 1-20.

Citation: Alex J. Rosburg et al. "Vertically-Suspended Environmental Enrichment Structures Improve the Growth of Juvenile Landlocked Fall Chinook Salmon”. International Journal of Innovative Studies in Aquatic Biology and Fisheries, 5(1), pp.17-24. http://dx.doi.org/10.20431/2454-7670.0501004

Copyright: () 2019 Authors. This is an open-access article distributed under the terms of the Creative Commons Attribution License, which permits unrestricted use, distribution, and reproduction in any medium, provided the original author and source are credited. 